\title{
INTRODUCTION
}

Situated in the Ure Valley $61 \mathrm{~km}$ from Blenheim, 'Peggioh' was purchased by the author in 1976 and farmed in partnership with another property owned by a brother. Since the termination of the partnership in 1978, 'Peggioh' has been farmed as a single, completely pastoral unit. During that time an intensive development programme has been undertaken with the help of finance from the Land Development Encouragement Loan scheme (L.D.E.L.), the Livestock Incentive Scheme (L.I.S.) and the Rural Bank.

The following is a summary of the policies, potential and problems of development in this summer dry environment.

\section{FARM DESCRIPTION}

Contour, Soils and Vegetation

Peggioh is 1306 ha in area and is basically long and narrow, being nearly $8 \mathrm{~km}$ front to back, which has a big effect upon management. The altitude increases from $150 \mathrm{~m}$ near the homestead (east) to $1057 \mathrm{~m}$ at the back (west).

Apart from 15 ha of stony river flats at the front, the soils and contour effectively divide the property into 2 distinct areas of hill, and have a marked effect on the native cover (table 1).

Table 1: SOILS AND VEGETATION AT 'PEGGIOH' IN 1976 AND AFTER 4 YEARS OF DEVELOPMENT (1978-82)

\begin{tabular}{llrr}
\hline Contour and soil type & Végetation Cover & 1976 & 1982 \\
\hline Steep (873 ha) & Unimproved tussock & 740 & 130 \\
Hurunui (840 ha) and & Improved tussock & 0 & 610 \\
Tekoa (33 ha) steepland & Heavy fern and scrub & 53 & 53 \\
soils & Bush and heavy scrub & 80 & 80 \\
Easy (433 ha) & Improved pasture & 130 & 262 \\
Kekerengu, Wharanui and & Heavy fern and scrub & 127 & 0 \\
Amuri (381); Flaxbourne \& & Burnt and oversown & 0 & 127 \\
Dashwood hill soils and & fern and scrub. & 176 & 44 \\
recent soils (52 ha) & Bush and heavy scrub & 176 & 4 \\
\hline \hline
\end{tabular}

The heavier limestone based soils on the easier contoured country are situated at the front (east) of the property, and the steeper country at the back contains the lighter greywacke based soils. 
In 1976 only 130 ha of some of the easier country had been improved by topdressing and oversowing.

Stock and Subdivision

In 1976 'Peggioh' was carrying 1820 halfbred sheep (including 1200 ewes) and 115 cattle (including 70 breeding cows) for a total of 2300 stock units. Stock production performance included an annual clip of $6,500 \mathrm{~kg}$ of wool (3.6kg/ewe), 60-65\% lambing survival-to-sale, with surplus stock sold as stores.

The property was set stocked throughout the year in four blocks in the back section and nine blocks in the front. One block of $\mathbf{4 4 5}$ ha in the back section carried 350 wethers. Under the extensive subdivision, water supply from creeks and springs was adequate at all times of the year.

Climate

Over the last 30 years annual precipitation has varied from 600 to $1600 \mathrm{~mm}$, with an average of $1150 \mathrm{~mm}$. Typically there is a dry spell in summer varying in intensity and length, but it usually persists from December through to March. On average August is the wettest month. Winters near the homestead are reasonably moderate, with between $\mathbf{4 0 - 5 0}$ frost days. Snow often lies on the back country but usually it has little effect on stock management. Spring growth is estimated to be 3-5 weeks later in the back compared with the front country.

\section{DEVELOPMENT}

Plans

The management on this property is in a process of evolution from an extensive grazing system with set stocking to a much more intensive system using rotational grazing. Thus the major management input has been directed toward farm development, along with the goal of substantially increasing stock numbers and their production performance. The stimulus for development came from the need to reduce a relatively high debt servicing burden, which was aggravated by the stock having low levels of production, and it also stemmed from the challenge of developing the large potential existing on the property.

Overall, development has been planned to fit within the constraints of contour and soil type, climate, shape and size of the property, as well as financial and management aspects. It was decided to initially concentrate on improving the heavier, easier country at the front followed by the steeper, lighter country at the back. This strategy was adopted because, although the per hectare costs of developing this country would be higher, it had greater potential, it was more accessible and easier to manage, and (at that stage anyway) the total costs of pasture establishment would be met by the L.D.E.L. scheme. Stock management changes planned included changing the breed of sheep from Halfbred to Romney on the front country, thus instituting a two-ewe-flock system, with halfbreds still to be run on the back portion. Also, in association with an intensive fencing programme, a rotational grazing system was implemented. Other developments planned included a large amount of new tracking for both stock and vehicle access, stock water dam construction,\& three further-sets of sheepyards to be built to minimise stock movement.

The time span for the development programme was largely fitted around the terms associated with the L.D.E.L. scheme. Thus for the first three years, developments were to be concentrated on the front country and in the fourth year most development was to occur on the back portion of the run. All land development 
costs were planned to be met from L.D.E.L. monies.

The method planned for the front country was to clear bush and heavy scrub during the summer by root-raking and burning the windrows. Heavy fern and associated patches of scrub were to be both burnt inside bulldozed firebreaks and root-raked. This would be followed by giant discing, then aerial oversowing with white clover/ryegrass in the late autumn (April), and topdressing. Tussock improvement was to be a simple case of oversowing pelleted clover seed and topdressing. Shady country was to have seed applied in early spring (3rd week in August) while the sunny country was to have seed applied in the autumn (April). New fencing on the front country was to all be electrified using both a mains and solar-powered energisers. Fencing on the back portion was to be conventional all-iron fences, due to the extreme steepness and difficulty of much of the terrain plus the difficulty of access for maintenance purposes.

\section{Practice}

Unfortunately, in practice substantial modifications have been made to planned methods, particularly in the front country. These changes have resulted directly from enormous increases in costs over the development period.

In the first year, 50 hectares were developed as planned and at a cost of $\$ 12,500$. In the second year increasing costs meant no discing was done, the land being cleared and then oversown. Further cost increases in each of the 3rd and 4th years have resulted in bulldozing being kept to a minimum and large amounts of clearing being done by burning, with extremely variable results. Often it is difficult to get a clean burn and fern regrowth is much more pronounced on burnt country, as opposed to that which has had some cultivation. More intensive sub-division than estimated is then necessary and also detrimental effects occur on stock when controlling the regrowth.

In view of the relatively high fertility status of the limestone soils and the high $\mathrm{pH}$ (6.3 in each of 3 tests) a calculated gamble was made by using unpelleted and cheaper seed mixes to further reduce costs. Initially $15 \mathrm{~kg}$ per hectare of pelleted seed (10 kg ryegrass, $5 \mathrm{~kg}$ white clover) had been used. This was changed to a cheaper $25 \mathrm{~kg}$ of aerial mix consisting mainly of ryegrass and white clover. The higher rate used was a hedge against possible lower germination. Initial establishment of pasture has been very good using this method, even allowing for one dry autumn.

Pelleted clover seed has been used for all the tussock development. The first block of 320 ha with a mixture of shady and sunny aspect had $4 \mathrm{~kg} / \mathrm{ha}$ of white clover applied in the spring. The second block of 100 ha of shady faces was done in the spring and had some red clover and alsike with the white clover. The third block of 190 ha of sunny country was oversown in the autumn and the white clover was supplemented with $3 \mathrm{~kg} / \mathrm{ha}$ of subterranean clover. For both these latter blocks the total seeding rate was $10 \mathrm{~kg} / \mathrm{ha}$.

Planned capital fertiliser applications of $350-400 \mathrm{~kg} / \mathrm{ha}$ on the front country and $300 \mathrm{~kg} / \mathrm{ha}$ on the back country have been adhered to right through the programme, despite an increase in price over four years of 225 percent. Annual maintenance applications of $150 \mathrm{~kg} / \mathrm{ha}$ on the back country and $200 \mathrm{~kg} / \mathrm{ha}$ on the front country have been recommended. However, only one maintenance application of $125 \mathrm{~kg} / \mathrm{ha}$ over the whole property has been made in the last two years. 


\section{Results to Date}

The present cover on the property is summarised in Table 1.

On the easy country 132 ha of land has been root-raked and sown down in pasture, with very good results. Variable results have been achieved with fern development, depending mainly upon the effectiveness of burning and subsequent grazing control. Clover establishment on the tussock country has been good.

The front portion of $\mathbf{4 3 3}$ ha of the run has been subdivided into 40 blocks and the back portion of 873 ha into 7 . The electric fences have been highly effective both in terms of stock control and in minimising costs. New tracks totalling $13 \mathrm{~km}$ have been constructed, including one of $7 \mathrm{~km}$ to the back of the property, which has improved access and ease of stock movement. A piped water reticulation scheme for 5 paddocks near the house and 16 stock water dams on the front country has been constructed. Other developments have included construction of 3 sets of sheepyards, extensions to the woolshed, and a quarter share of the cost of constructing a fertiliser bin.

Stock numbers have increased to 4320 stock units but they have remained static for the last two years. Wool production this year is expected to be 19,000 $\mathrm{kg}(4.4 \mathrm{~kg} / \mathrm{ewe})$ and lambing $90 \%$ survival-to-sale. Even allowing for an increase of 2000 s.u., debt servicing is still the same on a s.u. basis, due mainly to increased interest rates on those mortgages existing before development began. However, the ratio of total mortgage servicing to total farm income has dropped from 42 to 28 percent, a direct result of increased productivity of the stock.

\section{FUTURE PRODUCTION INCREASES}

These are largely dependant upon financial, rather than management or technical, constraints. At this stage some development consolidation is being made both in pastures and stock. Over the next four years stock numbers are planned to increase at a slower rate to a total of 5000 stock units. Of this 700 s.u. increase, 500 s.u, will be in cattle. This is a direct result of the need for control of fern regrowth and to clean up dry pasture 'tag' resulting from excess spring pasture production. Up until now cattle numbers have been minimal because of their lower profitability and consequent debt servicing ability. Income on a stock unit basis is expected to increase with consolidation, which will further ease the burden of debt servicing, Targets of $100 \%$ lambing survival to sale, at least $4.6 \mathrm{~kg}$ of wool per ewe, and surplus lambs being sold prime have been set as achievable levels of sheep performance. Given these target constraints, the potential carrying capacity of the property has been assessed as:

\begin{tabular}{lllll} 
Developable & Back & Country & 400 ha @ 10 s.u./ha & 4000 \\
Developable & Back & Country & 790 ha @ 4.5 s.u./ha & 3555 \\
\hline & & &
\end{tabular}

Achievement-of-the-extra-possible-2500-s:u-above-the-5000-already-planned for depends largely upon removal of the labour restriction of operating the property as a one-family unit. Once again, the elimination of this obstacle is largely contingent upon financial considerations. 